\title{
Introduction to Special Issue about Election Reporting: Why Journalism (Still) Matters
}

\author{
Stephen Cushion and Daniel Jackson (Jacksond@Bournemouth.ac.uk)
}

\author{
Corresponding contact: cushionsa@cardiff.ac.uk
}

\begin{abstract}
This introduction unpacks the eight articles that make up this Journalism special issue about election reporting. Taken together, the articles ask: How has election reporting evolved over the last century across different media? Has the relationship between journalists and candidates changed in the digital age of campaigning? How do contemporary news values influence campaign coverage? Which voices - politicians, say or journalists - are most prominent? How far do citizens inform election coverage? How is public opinion articulated in the age of social media? Are sites such as Twitter developing new and distinctive election agendas? In what ways does social media interact with legacy media? How well have scholars understood election reporting cross-nationally? How can our research agendas be enhanced?

Overall, we argue this special issue demonstrates the continued strength of news media during election campaigns. This is in spite of social media platforms increasingly disrupting and recasting the agenda setting power of legacy media, not least by political parties and candidates who are relying more heavily on sites such as Facebook, Instagram and Twitter to campaign. But while debates in recent years have centred on the technological advances in political communication and the associated role of social media platforms during election campaigns (e.g. microtargeting voters, spreading disinformation/misinformation and allowing candidates to bypass media to campaign), our collection of studies signal the enduring influence professional journalists play in selecting and framing of news. Put more simply, how elections are reported still profoundly matters in spite of political parties' and candidates' more sophisticated use of digital campaigning.
\end{abstract}

Keywords: Election reporting; agenda-setting; hybrid media; mediatization of politics; social media; political communication; political journalism

Election reporting represents one of the most studied areas of journalism studies. From longstanding debates about agenda-setting (McCombs and Shaw 1972) to interpreting bias, objectivity and impartiality (D'Alessio 2012), to more recent inquiries about the mediatization of politics (Stromback and Esser 2014) and the consequences of hybrid media systems (Chadwick 2013), election campaigns have provided the backdrop to many of the most prominent debates and theoretical advances about the media's role in the political process. This is in recognition of the crucial role the news media play in engaging and informing voters during election campaigns (Semetko et al 1991). As a consequence, scholars have long explored the role and influence of journalism and journalists during campaigns in order to establish how well they serve citizens ahead of election day (Cushion and Thomas 2018).

In today's complex and increasingly fragmented media environment, elections are reported from an ever-expanding range of content platforms and providers, communicating 
news about issues, candidates and the campaign in ways that reinforce and challenge long established journalistic norms and routines (Graber and Dunaway 2018). Meanwhile, journalists covering campaigns operate in an increasingly professionalised communication environment, competing not only with more media savvy spin doctors controlling the message but new technologies and data harvesting software that allows candidates to eschew the channels of communication traditionally overseen by journalists and appeal directly to voters (Kreiss 2016; Strömbäck and van Aelst 2013; Stroud and McGregor 2018). In the hands of powerful and populist leaders, such as Donald Trump and Jair Bolsonaro, these tools offer a direct challenge to the authority of journalists as mediators of public debate (Aalberg et al 2017; Lawrence and Boydstun 2016). At the same time, journalism - whether justified or not - must recover from its association with 'fake news' and election interference which has beset recent elections in the West (Bakir and McStay 2018).

Against this backdrop, this special issue offers new empirical and theoretical insights about these new and evolving journalistic practices during election campaigns from a range of competing but intersecting perspectives. The collection of articles grew from an ICA 2018 pre-conference in Prague. Taken together, the conference papers were rich in scope and focus, reflecting the multiplicity of challenges journalists face when reporting campaigns. Participants, for example, addressed the increasing partisanship and politicisation of political journalism; how voters, public opinion and election outcomes are constructed by journalists; the role played by social media and digital campaigning in shaping coverage; the types of news values and journalistic framing pursued in a hybrid media system, and whether a digital agenda is being re-set with the emergence of new alternative media outlets.

In selecting papers for this special issue of Journalism, we were conscious of ensuring geographical balance and a diverse thematic make-up, as well as evaluating the methodological strength, empirical depth and theoretical insight of each contribution.

While acknowledging that the national, cultural and historical context of an election shapes the reporting of a campaign, we wanted to push beyond national concerns and issues to bring light to the systematic drivers of news production, content and effects during campaigns.

Overall, we have assembled a wide-ranging mix of papers that, for us, captures the direction in which scholarship on election news is and should be heading. Taken together, the articles in this special issue reflect the changing nature of journalism studies and political communication research and scholarship. These interconnected features include:

- A shift away from the study of single platforms and news sectors, towards hybrid media environments, where the informational and persuasive agendas of political elites, journalists (representing mainstream and alternative media alike), grassroots campaigners and citizens intersect and overlap.

- Methodological plurality and innovation. The research questions that drive some of our special issue contributions push them to move beyond traditional methods, such as content analysis and surveys. Social media are obviously central to such analyses, but this does not lead to inward-looking 'dead ends' of social media analysis that are separated from other media and political communication. Instead, contributors carefully examine the multiple platforms in which election reporting and associated political communication take place.

- Asking novel and timely questions that push the frontiers of knowledge in the field. This special issue includes, for example, the first longitudinal analysis of election reporting in South Africa and a unique 100-year longitudinal examination of election 
news in the UK. Other studies ask: has the relationship between journalists and candidates changed in the digital age of campaigning? How do contemporary news values influence campaign coverage? Which voices - politicians, say or journalists are most prominent? How far do citizens inform contemporary election news coverage? How is public opinion articulated in the age of social media? Are sites such as Twitter developing new and distinctive election agendas? In what ways does social media interact with legacy media? How well have scholars understood election reporting cross-nationally? How can our research agendas be enhanced?

But this special issue - we must say - also reminds us of some of our limitations as a field. Clearly - and as Frank Esser observes in his contribution to this special issue - research addressing election reporting could benefit from more cross-national comparative studies, identifying ways of developing new theoretical inquires and advancing knowledge about the role and value of different media and political systems. We also need to find more effective ways of de-Westernizing our field in order to produce a more global understanding of election reporting. In this special issue, we bring together contributions from the US, UK, Italy, Austria, South Africa and Australia. But as comparative journalism studies research continues to remind us, there are many different types of political and media environments across the world meaning the export of Western theories of journalism and political communication may not always help in understanding election reporting on a global level (Hanusch and Vos 2019; Mellado et al. 2017).

Taken together, we would argue that our special issue demonstrates the continued strength of news media during election campaigns. This is in spite of social media platforms increasingly disrupting and recasting this the agenda setting power of legacy media in new and interesting ways, not least by political parties and candidates who are relying more heavily on sites such as Facebook, Instagram and Twitter to campaign. While debates in recent years have centred on the technological capability of parties and candidates and their micro-targeting of voters (Chadwick and Stromer-Galley 2016; Kreiss 2016), our collection of studies signal the enduring influence professional journalists play in selecting and framing news that citizens remain reliant on for information during an election campaign. Put more simply, how elections are reported still profoundly matters in spite of political parties and candidates more sophisticated use of digital campaigning.

The special issue begins with David Deacon and Emily Harmer's detailed 100-year content analysis study of national press coverage of UK general elections. They explore four key areas of political reporting that are widely claimed to be increasing in most advanced Western democracies. First, presidentialisation of coverage, which relates to reporting centring on party leaders rather than parties and other politicians. Second, personalisation, which represents coverage that focusses on the personal lives of political candidates. Third, editorial negativity towards politicians and fourthly, enhanced process coverage, which symbolises policy being relegated for news about the campaign, party strategy or horse race content (Jackson 2014). Their findings, overall, problematize sweeping generalisations about changing patterns of election campaigns. While they show some evidence to support changes in the four areas examined, they identify important nuances that challenge historically linear accounts of political reporting. So, for example, they find negativity in election coverage was enhanced post-1990s, which they interpret as being connected to the rise of spin. Similarly, they discover a steady increase in coverage of party leaders, which - they argue - was primarily exacerbated by oppositional leaders gaining more coverage post-war. With process 
coverage, their findings "provide no evidence of a clear shift over time and reveal considerable election-by-election volatility. Moreover, they challenge claims that there has ever been a time when 'issue orientation' prevailed". They also find that as far as these four indicators go, interwar and immediate post-World War II coverage was not that different, despite huge technological, social and cultural changes. Overall, Deacon and Harmer's forensic analysis demonstrates the value of longitudinal studies and of interpreting any shifts within the micro and macro context of wider political, social and economic issues and events. The findings of this study will reverberate through the fields of journalism studies and political communication.

Our next article represents another important longitudinal intervention into historical shifts in election reporting, but in a developing country. Bernadine Jones' study of television reporting in South African elections between 1994 and 2004 examines, in detail, the role and use of sources over 5 post-apartheid election campaigns. In doing so, Jones discovers that while the voices of pundits became a more prominent fixture of campaign coverage, correspondingly political leaders and citizens were marginalised. She argues that relying on non-elected professional commenters risks alienating viewers from the political classes as well as limiting the extent to which citizens directly shape the news agenda. This is particularly significant - as the study explores - in a developing country such as South Africa because citizens need to feel part of the democratic process for the governing institutions to be accepted and legitimatised. In explaining the elevated role of commentators, the article concludes that coverage is symbiotic of a mediatization of politics, which has also influenced Western political journalism. According to Jones, the shift towards a more media-orientated agenda is a consequence of the fraught relationship between journalists and politicians, and under-funded newsrooms and poorly trained reporters, with professional pundits relied upon to fill airtime during the campaign. The mediatization of politics, viewed in this context, represents an assertion of media power in a young democracy struggling to resolve economic, social and racial tensions. In many ways, this study extends how we understand mediatized politics (a largely Western concept) in developing world contexts.

Examining contemporary news coverage, Stephanie Brookes offers a comparative assessment of how journalists in Australia and the United States (US) consider their role in reporting election campaigns. By studying metajournalistic discourse, this article explores the identity and authority of reporters, bringing to light the professional dilemmas that face journalists at the front line of an election campaign. Drawing on interviews with 29 current and former reporters across a range of news media, she asks how journalism should function during a campaign in today's fragmented and competitive media environment. The focus, in particular, is on whether reporters should continue to deliver 'on the bus' coverage, travelling with candidates in order to witness and report campaign events and speeches. Since party political party management increasingly limit access and closely stage-manage candidates so they stay 'on message', interviewees questioned the time and resources invested in this approach to reporting. On balance, however, Brookes' discovered that most journalists subscribed to the view that being 'up close and personal' with candidates and their entourage merited the newsroom expenditure and journalistic endeavour. In their own words, her interviewees described important eyewitness moments that revealed insights into the campaign that would not have been possible if reporters had watched coverage live on 24hour news or following a Twitter feed. So, for example, one US reporter acknowledged that attending Donald Trump's campaign rallies during the 2016 Presidential elections exposed 
journalists to the passion and convictions of his supporters. Overall, Brookes' study demonstrates the importance of not just hearing first-hand from reporting in journalism, but in critically assessing how and why they make editorial judgements about campaign coverage.

From a different perspective, Kathleen Searles and Kevin Banda's study of news values reinforces the need for questioning routine journalistic judgement during an election campaign. They examine television news reporting of the 2016 US Presidential election campaign to in order to explore what types of stories are given priority and considered the most 'newsworthy'. In doing so, they develop a model for understanding the choices journalists made in how they reported Clinton and Trump. Searles and Banda's content analysis identified that both candidates received more horse race coverage than coverage of either scandals or issues. Moreover, both candidates were reported to the same extent in horse race coverage, whereas in news about scandal they were treated differently. Clinton - the frontrunner in the contest - featured in significantly more scandal coverage than Trump despite many of his transgressions during the campaign. They account for this imbalance by arguing that well-known frontrunners - such as Hillary - are more likely to attract media attention about any scandals than investigating emerging scandals of a trailing candidate. According to Searles and Banda, this represents a rational journalistic preference, a calculated editorial choice, rather than an arbitrary end product. They suggest their model of understanding editorial decision-making can help not only make sense of the issues that make the news agenda, but it can also help explain the relative degree of volume of coverage for newsworthy stories. Significantly, their study has profound consequences for achieving fair and balanced reporting during election campaigns, since preferential choices for different candidates can favour the interests of one candidate or party over another. In this case study, Searles and Banda conclude that Trump was not held to account in the same way as his opponent, representing a journalistic failure that may have contributed to the outcome of the 2016 Presidential election.

Focussing on the same election campaign, Shannon McGregor exposes another imbalance in media coverage by examining the way journalists construct public opinion. Just as news values reflect long established norms and practices in reporting, she argues social media was used to create false pictures of public opinion during the campaign, as well as promoting the horse race narrative, which is already prevalent in US election reporting. Drawing on a content analysis of a range of cable news, digital-native publishers, magazines, network TV, newspapers and public broadcasting, McGregor finds social media posts notably Twitter - are used by journalists to reflect the weight of the public's view on an issue, event or candidate, despite the fact that they represent a partial and often partisan reflection of 'public opinion'. Through interviews with 18 journalists, she discovers that, far from being cautious about conveying public views, editors encourage journalists to include individual social media posts that appear on their own Twitter feeds. Like vox populi, she suggests social media posts have become routinized as a quick-fix way of delivering instant responses and reactions. But, in doing so, it can potentially not only misrepresent public opinion, it can have a spiralling effect of informing future news judgements and the development of new narratives. Overall, McGregor argues this growing reliance on social public opinion risks promoting the loudest and most polarized viewpoints, further exacerbating the already highly partisan and conflictual nature of US political reporting. While social media opens up new 
ways of imagining the public, she suggests journalists should continue to rely on more accurate quantitative measures of data to convey public opinion.

Reinforcing the power of social media in journalistic echo chambers, Josef Seethaler and Gabriele Melischek's analysis of the 2017 Austrian national election demonstrates how Twitter is fast becoming a powerful agenda setting campaign tool for political parties. Their study establishes that the main parties' respective Twitter feeds enhance the prospects of their messages shaping election reporting. This was not explained by the strategic use of Twitter, but largely by the messages conveyed in the social media accounts of the party headquarters. When isolating the impact of Twitter use among different parties, the study found that the most powerful incumbent parties were most successful in setting the agenda. In other words, as a campaign tool, Twitter perpetuates the status quo, transferring their dominance to the new, hybrid media environment. Overall, Seethaler and Melischek argue that the parties' use of Twitter represents a new agenda-building power in campaigning, a challenge to the mediatization of politics thesis. Their study suggests that rather than pursuing a more independent media agenda, journalists are relying on main parties' tweets to formulate editorial decisions about election story selection.

Twitter is not just a campaign tool to help set the news agenda, it also represents a type of public sphere (Bruns and Highfield, 2016) where citizens can interact with mainstream media content and potentially drive the conversation of the broader 'Twittersphere'. But the extent to which this public sphere is layered by echo chambers has remained a pressing question, which Andrea Ceron and Sergio Splendore take up. Through a lead-lag analysis of the tweeting behaviour of the general 'Twitersphere', and a more elite group of 'second screeners' (who watched and actively commented on nine political talk shows during the 2016 Italian constitutional referendum campaign) they examine the dynamics of agenda setting in hybrid media environments. They find that second screeners (and by extension, the agendas of the political talk shows) are successful in setting the agenda of broader public attention during a campaign. However, when it comes to second order agenda setting - influencing the attitudes of the broader Twittersphere - second screeners are not able to anticipate the mood of other social media users. These findings therefore point towards the limited impact of political media outside of elite networks, as well as the broader conundrum of polarized echo chambers (Garret, 2009) that do not seem to talk to each other.

In the final article, Frank Esser considers the role and value of comparative research in election reporting, outlining their achievements to date but also their future challenges. Acknowledging the lack of cross-national communication generally, he draws attention to the lack of internationally comparative studies systematically examining election reporting, particularly online and social media platforms. This is explained, in part, due to limited resources rather than the willingness of researchers to network, coordinate and collaborate. Of the existent literature on elections that empirically examine coverage between countries, Esser identifies nine areas of focus. First, the degree and prominence of political actors in the news. Second, the balance between policy and process reporting. Third, the personalisation of coverage. Fourth, the framing of politics as a game or horserace. Fifth, the tone and evaluation of actors and issues. Sixth, the level of negativity. Seventh, the degree of conflict in news stories. Eighth, how far journalists intervene in politics coverage. Finally, ninth, the style and form of populist politics. While Esser draws attention to the range of topics addressed, he argues that greater conceptual clarity is needed when defining and operationalising terms such as populism. Overall, he calls for more collaborative research in 
journalism studies, encouraging scholars to examine the interplay between legacy and new online and social media platforms in order to more fully understand election reporting in today's hybrid media and campaigning environment.

\section{References}

Aalberg T Esser F Reinemann, C Strömbäck J and de Vreese, C. H. eds (2017) Populist Political Communication in Europe. Abingdon: Routledge.

Bakir V and McStay A (2018) Fake News and The Economy of Emotions, Digital Journalism 6:2: 154-175

Bruns, A and Highfield, T (2016) Is Habermas on Twitter? Social media and the public sphere. In Bruns, Enli, G, Skogerbo, E, Larsson, A and Christensen, C (Eds) The Routledge companion to social media and politics. London; Routledge, pp. 56-73.

Chadwick A (2013) The Hybrid Media System: Politics and Power. Oxford: Oxford University Press.

Chadwick A and Stromer-Galley J (2016) Digital media, power, and democracy in parties and election campaigns: party decline or party renewal? International Journal of Press/Politics 21(3): 283-93.

Cushion S and Thomas R (2018) Reporting Election: Rethinking the Logic of Campaign. Cambridge: Polity Press.

D’Alessio D (2012) Media Bias in Presidential Election Coverage, 1948-2008: Evaluation via Formal Measurement. Lanham, MD: Lexington Books.

Esser F and Strömbäck J (2014) (eds), Mediatization of Politics: Understanding the Transformation of Western Democracies. Basingstoke: Palgrave Macmillan

Graber DA and Dunaway J (2018) Mass media and American politics (10 ${ }^{\text {th }}$ edition). London: Sage.

Hanusch F and Vos T P (2019). Charting the development of a field: A systematic review of comparative studies of journalism. International Communication Gazette. Ifirst.

Garret RK (2009) Echo chambers online? Politically motivated selective exposure among Internet news users. Journal of Computer-Mediated Communication 14, 265-285.

Jackson D 2014. Time to get serious? Process news and British politics. In Broersma M and Peters C (Eds). Retelling Journalism: Conveying Stories in a Digital Age. Leuven: Peeters.

Kreiss D (2016) Prototype Politics: Technology-Intensive Campaigning and the Data of Democracy. Oxford: Oxford University Press.

Lawrence R and Boydstun AE (2016) What We Should Really Be Asking About Media Attention to Trump. Political Communication/The Forum 34(1): 1503.

Mellado C Hellmueller L Márquez-Ramírez M Humanes M L Sparks C Stepinska A Pasti S Schielicke Anna-Maria Tandoc E and Wang H (2017) The Hybridization of Journalistic Cultures: A Comparative Study of Journalistic Role Performance. Journal of Communication 1-24

Semetko H. A., Blumler J G Gurevitch M., and Weaver D H (1991) The Formation of Campaign Agendas: A Comparative Analysis of Party and Media Roles in Recent American and British Elections. Hillsdale, NJ: Erlbaum. 
Strömbäck, Jesper \& Van Aelst, Peter (2013). Why Political Parties Adapt to the Media: Exploring the Fourth Dimension of Mediatization. International Communication Gazette, 75(4), 341-358.

Stroud T J and McGregor S C (Eds.) (2018) Digital Discussions: How Big Data Informs Political Communication. Routledge.

\section{Author biographies}

Dr Stephen Cushion is a Reader at Cardiff University School of Journalism, Media and Culture. He has written three sole authored books, News and Politics: The Rise of Live and interpretive Journalism, The Democratic Value of News: Why Public Service Media Matter (2012, Palgrave) and Television Journalism (2012, Sage), one co-authored book, Reporting Elections: Rethinking the Logic of Campaign Coverage (2018, Polity Press, with Richard Thomas) and co-edited The Future of 24-Hour News: New Directions, New Challenges (2016, Peter Lang, with Richard Sambrook) and The Rise of 24-Hour News: Global Perspectives (2010, Peter Lang with Justin Lewis). He has also published over 70 journal articles, book chapters or research reports on issues related to news, politics and journalism. He is an Associate Editor of Journalism Studies.

Dr Dan Jackson is a Senior Lecturer in Media and Communications at The Media School, Bournemouth University. His research broadly explores the intersection of media and democracy, including news coverage of politics, the construction of news, political communication and political talk online. 